\title{
FAKTOR DETERMINAN PERILAKU CUCI TANGAN PAKAI SABUN (CTPS) PADA MASYARAKAT DI TANAH KALIKEDINDING
}

\author{
DETERMINANT FACTOR OF HANDWASHING WITH SOAP (CTPS) IN PEOPLE \\ ON THE TANAH KALIKEDINDING
}

\author{
Gracia Risnawaty \\ Departemen Administrasi dan Kebijakan Kesehatan \\ Fakultas Kesehatan Masyarakat Universitas Airlangga \\ Email: graciarisnawaty@yahoo.co.id
}

\begin{abstract}
One of the factors that are considered important for the development of social welfare in Indonesia is health. Based on data from the WHO, diarrhea and ARI (Acute Respiratory Infection) is an infectious disease remains a health problem in Indonesia. From the data obtained in 2015, it is known that the village Tanah Kalikedinding RW II (RT 07 and 11) has a health problem with the number of diarrhea and ARI are quite high, as many as 2.467 cases of diarrhea and 15.207 cases for patients with respiratory infection. The purpose of this research is to find information about the relationship between knowledge and attitudes toward behavior handwashing (CTPS) in the village Tanah Kalikedinding. The research method is analytic with cross sectional approach. The population in this study is the whole community in the village Tanah Kalikedinding. A total sample of 70 people were selected using simple random sampling. The research variables are gender, age, knowledge, education, employm ent, attitudes and behaviors CTPS. The primary data obtained from interviews and questionnaires, while secondary data obtained from the data clinic. The results showed a determinant factor in the behavior of people in the CTPS divided into three driving factors are gender, age, knowledge, education, employment, attitudes and behaviors CTPS, enabling factors such as facility and reinforcing factors are health workers. It is necessary to attempt a programmed extension activities, sustainable, evaluation and monitoring at regular intervals in each program activity CTPS on society as well as involving cross-sector cooperation in every program CTPS on society.
\end{abstract}

Keywords: knowledge, attitudes, behavior, CTPS

\begin{abstract}
Abstrak: Salah satu faktor yang dianggap penting untuk pembangunan kesejahteraan penduduk di Indonesia adalah kesehatan. Berdasarkan data dari WHO, diare dan ISPA (Infeksi Saluran Pernapasan Akut) yang merupakan penyakit menular masih menjadi masalah kesehatan di Indonesia. Dari data yang diperoleh pada tahun 2015 diketahui bahwa Kelurahan Tanah Kalikedinding RW II (RT 07 dan 11) Kecamatan Kenjeran Kota Surabaya memiliki masalah kesehatan dengan angka penderita diare dan ISPA yang cukup tinggi yakni 2.467 kasus diare dan sebanyak 15.207 kasus untuk penderita ISPA. Tujuan dari penelitian ini adalah mencari informasi tentang hubungan antara pengetahuan dan sikap terhadap perilaku Cuci Tangan Pakai Sabun (CTPS) di Kelurahan Tanah Kalikedinding. Metode penelitian merupakan analitik dengan pendekatan cross sectional. Populasi dalam penelitian ini adalah seluruh masyarakat di Tanah Kalikedinding. Jumlah sampel sebanyak 70 orang yang dipilih dengan menggunakan cara simple random sampling. Variabel penelitian yaitu jenis kelamin, umur, pengetahuan, pendidikan, pekerjaan, sikap dan perilaku CTPS. Diperoleh data primer dari hasil wawancara dan kuesioner, untuk data sekunder diperoleh dari data puskesmas. Hasil penelitian menunjukkan faktor determinan pada masyarakat dalam perilaku CTPS terbagi menjadi tiga yaitu faktor pendorong, faktor pemungkin dan faktor penguat. Maka perlu dilakukan upaya kegiatan penyuluhan yang terprogram, berkelanjutan, upaya evaluasi dan monitoring secara berkala dalam setiap program kegiatan CTPS pada masyarakat serta melibatkan kerjasama lintas sektor dalam setiap program CTPS pada masyarakat.
\end{abstract}

Kata kunci: pengetahuan, sikap, perilaku, CTPS

\section{PENDAHULUAN}

Kesehatan adalah suatu keadaan sehat, baik secara fisik, mental, spiritual maupun sosial yang memungkinkan setiap orang dapat hidup produktif secara sosial dan ekonomis yang tertuang dalam Undang Undang Republik Indonesia Nomor 36 tahun 2009 tentang Kesehatan. Salah satu faktor yang dianggap penting dalam pembangunan 
kesejahteraan penduduk di Indonesia adalah kesehatan. Akan tetapi masalah kesehatan di Indonesia masih banyak ditemukan dan harus diselesaikan. Berdasarkan data dari WHO (World Health Organization), diare dan ISPA (Infeksi Saluran Pernapasan Akut) yang merupakan penyakit menular masih menjadi masalah kesehatan yang ada di Indonesia.

Perolehan data yang didapatkan dari Center Disease Control (CDC) Amerika Serikat, terdapat 10.080 kematian dengan lebih dari 80\% kematian diakibatkan karena diare. Di Asia selatan yaitu India terdapat 0,4 juta anak meningal dalam satu tahun yang disebabkan oleh diare. (Journal of Harvard School of Public Health)

Berdasarkan Riskesdas tahun 2013, insiden diare pada balita sebesar $6,7 \%$ (kisaran menurut provinsi 3,3\%-10,2\%) dan insiden diare ( $\leq 2$ minggu terakhir sebelum wawancara) dengan gejala pada seluruh kelompok umur sebesar 3,5\% (menurut provinsi pada kisaran 1,6\%-6,3\%). Sedangkan period prevalence diare pada balita sebesar $10,2 \%$ dan pada seluruh kelompok umur $(>2$ minggu-1 bulan terakhir sebelum wawancara) berdasarkan gejala sebesar $7 \%$. Terdapat keluhan kesehatan yang paling sering dialami oleh balita pada tahun 2014 yaitu pilek $(66,62$ $\%)$, batuk $(63,76 \%)$ dan panas $(62,52 \%)$ merupakan penyakit yang paling sering dialami balita baik di perkotaan maupun di pedesaan. (Kementerian Kesehatan Republik Indonesia, 2014)

Palancoi pada tahun 2014, melakukan sebuah penelitian yang menyatakan bahwa, terdapat beberapa faktor yang mempengaruhi adanya kejadian diare yaitu perilaku, pengetahuan dan lingkungan tentang diare. Perilaku kesehatan adalah suatu stimulus atau objek dari respon seseorang yang berkaitan dengan sakit dan penyakit, makanan, minuman, sistem pelayanan kesehatan dan lingkungan (Notoatmodjo, 2010).

Provinsi Jawa timur merupakan salah satu provinsi terjadinya KLB Diare yaitu 258 kasus dan kasus tertinggi ISPA sebesar 28,3 \% Berdasarkan data kesehatan Provinsi Jawa Timur, kejadian diare dan ISPA masih cukup tinggi. Terdapat kasus ISPA sebesar 15207 penderita dan 2467 penderita diare pada tahun 2015 di Kelurahan Tanah Kalikedinding Kecamatan Kenjeran Kota Surabaya. (Kemenkes RI, 2014)
Cuci tangan pakai sabun sebagai upaya preventif dalam melindungi diri dari berbagai penyakit menular. Cuci tangan menggunakan sabun dapat kita lakukan pada waktu-waktu berikut: sebelum menyiapkan makanan, sebelum dan sesudah makan, setelah BAK dan BAB, setelah membuang ingus, setelah membuang dan atau menangani sampah, kemudian setelah bermain/memberi makan/memegang hewan, serta setelah batuk atau bersin pada tangan kita (Desiyanto dan Djannah, 2012).

Cuci tangan pakai sabun yang dipraktikkan secara tepat dan benar merupakan cara termudah dan efektif untuk mencegah berjangkitnya penyakit. Mencuci tangan dengan air dan sabun dapat lebih efektif menghilangkan kotoran dan debu secara mekanis dari permukaan kulit dan secara bermakna mengurangi jumlah mikroorganisme penyebab penyakit seperti virus, bakteri dan parasit lainnya pada kedua tangan. Mencuci tangan dengan menggunakan air dan sabun dapat lebih efektif membersihkan kotoran dan telur cacing yang menempel pada permukaan kulit, kuku dan jari-jari pada kedua tangan (Desiyanto dan Djannah, 2012).

Hendrik L. Blum di dalam Notoatmodjo (2010) secara jelas mengungkapkan bahwa terdapat empat faktor utama yang berkaitan dalam derajat kesehatan seseorang, kelompok dan masyarakat yaitu perilaku, pelayanan kesehatan, lingkungan dan keturunan atau herediter. Faktor - faktor tersebut memiliki keterkaitan dalam mempengaruhi derajat kesehatan masyarakat dan kesehatan perorangan.

Diantara empat faktor tersebut faktor determinan yang paling berpengaruh besar adalah faktor perilaku manusia dan disusul faktor lingkungan pada urutan kedua. Hal ini dapat terjadi akibat faktor perilaku memiliki pengaruh lebih besar dari faktor lingkungan sehingga lingkungan hidup manusia juga sangat dipengaruhi oleh perilaku masyarakat (Notoatmodjo, 2010).

Kebiasaan dalam cuci tangan menggunakan air saja tidak dapat melindungi setiap individu dari bakteri dan virus yang terdapat di tangan. Terlebih jika mencuci tangan tidak dibawah air mengalir. Apalagi kebiasaan menggunakan dan 
berbagi wadah cuci tangan hal itu sama saja saling berbagi kuman dan tetap membiarkan kuman menempel pada tangan. Kebiasaan itu harus ditinggalkan dan dirubah menjadi yang lebih baik dengan standar prosedur melakukan cuci tangan menggunakan sabun (Kemenkes RI, 2014).

Indikator PHBS (Perilaku Hidup Bersih dan Sehat) salah satunya mencuci tangan dengan air mengalir dan sabun yang merupakan sekumpulan perilaku yang dilakukan karena kesadaran dari hasil pembelajaran, yang membuat individu atau keluarga dapat menjaga dan memelihara kesehatan serta berperan aktif untuk mewujudkan masyarakat sehat. Salah satu pilar utama dalam Indonesia Sehat dan merupakan salah satu strategi untuk mengurangi beban negara dan masyarakat terhadap pembiayaan kesehatan yaitu PHBS (Kemenkes RI, 2014).

Cara CTPS yang benar adalah menggosok telapak tangan secara bersamaan, menggosok punggung kedua tangan, jalinkan kedua telapak tangan lalu digosok-gosokkan, tautkan jari-jari antara kedua telapak tangan secara berlawanan, gosok ibu jari secara memutar dilanjutkan dengan daerah antara jari telunjuk dan ibu jari secara bergantian, gosok kedua pergelangan tangan dengan arah memutar, bilas dengan air dan keringkan. Hal terpenting dalam CTPS bukan berapa lama waktu mencuci tangan, tetapi cara mencuci tangannya (Kemenkes RI, 2014).

Menggunakan sabun saat mencuci tangan diketahui sebagai salah satu upaya pencegahan penyakit dan penularan penyakit. Hal ini dilakukan karena tangan merupakan agen yang membawa kuman dan menyebabkan patogen berpindah dari satu orang ke orang lain, baik dengan kontak tidak langsung maupun kontak langsung (menggunakan permukaan lain seperti handuk dan gelas) (Kemenkes RI, 2013).

Hal ini mengindikasikan bahwa perilaku cuci tangan menggunakan sabun merupakan suatu upaya yang memiliki dampak besar bagi pencegahan penyakit-penyakit menular seperti diare dan ISPA, namun mencuci tangan masih belum menjadi kebiasaan pada masyarakat. Tentunya hal ini masih dipengaruhi oleh banyak hal diantaranya karena rendahnya pengetahuan, pendidikan dan kesadaran terhadap perilaku cuci tangan pakai sabun. (Kemenkes RI, 2014)

Menurut penelitian yang telah dilakukan oleh Grayson et al pada tahun 2009, mencuci tangan menggunakan sabun maupun dengan menggunakan pencuci tangan berbasis alkohol memberikan efektifitas dalam mengurangi konsentrasi virus pada tangan.

Pada penelitian yang dilakukan Rahim (2007), juga mengungkapkan bahwa cuci tangan pakai sabun (CTPS) dapat mencegah infeksi cacingan (Mustika, 2011). Bila tidak mencuci tangan menggunakan sabun, dapat menularkan infeksi pada diri sendiri terhadap bakteri dan virus dengan memegang bagian hidung, mata dan mulut. Selain itu juga dapat menyebarkan atau menularkan bakteri kepada orang lain. Penyakit infeksi biasanya terjangkit melalui kontak tangan ke tangan termasuk flu dan common cold. Pada tangan yang kurang bersih tidak hanya dapat menyebabkan ISPA dan diare tetapi juga dapat menimbulkan penyakit terkait infeksi bakteri Salmonella dan E.coli (Lestari, 2008).

Berdasarkan uraian data masalah dan penelitian diatas, sehingga penelitian ini berfokus pada tujuan untuk mengetahui faktor determinan perilaku Cuci Tangan Pakai Sabun (CTPS) pada masyarakat di Kelurahan Tanah Kalikedinding RW II (RT 07 dan RT 11) Kecamatan Kenjeran Kota Surabaya. Hasil penelitian ini diharapkan bermanfaat bagi Dinas Kesehatan dan Puskesmas Tanah Kalikedinding serta dapat dijadikan sebagai sumber informasi untuk menurunkan angka kejadian ISPA dan Diare di Kelurahan Tanah Kalikedinding RW II (RT 07 dan RT 11) Kecamatan Kenjeran Kota Surabaya.

\section{METODE}

Penelitian ini menggunakan metode deskriptif. Penelitian dilaksanakan di Kelurahan Tanah Kalikedinding RW II (RT 07 dan 11) Kecamatan Kenjeran Kota Surabaya. Pengolahan data yang digunakan adalah data primer yang diambil langsung dengan wawancara dan pengisian kuesioner. Sedangkan data sekunder didapatkan dari dokumen Puskesmas Tanah Kalikedinding. 
Populasi pada penelitian ini adalah seluruh masyarakat di Kelurahan Tanah Kalikedinding RW II (RT 07 dan 11) Kecamatan Kenjeran Kota Surabaya dengan jumlah keseluruhan populasi sebesar 839 jiwa dan besar sampel yang dipakai pada penelitian ini berjumlah 70 orang yang ditentukan berdasarkan perhitungan rumus Slovin. Sampel dipilih dengan menggunakan cara acak sederhana (simple random sampling). Waktu penelitian dilakukan selama 2 hari yaitu pada tanggal 08 sampai 11 Februari 2016.

Analisis data yang dilakukan secara univariat dimana menjelaskan karakteristik masing-masing variabel penelitian dengan cara menyusun distribusi frekuensi variabel -variabel penelitian tersebut.Variabel Independent tersebut adalah jenis kelamin, umur, pendidikan, pekerjaan, pengetahuan, sikap dan variabel dependet adalah perilaku CTPS.

\section{HASIL PENELITIAN}

Analisa univariat dilakukan untuk mendeskripsikan dari setiap variabel independen yaitu jenis kelamin, umur, pendidikan, pekerjaan, pengetahuan dan sikap sedangkan untuk variabel dependen yaitu perilaku mencuci tangan menggunakan sabun. Karakteristik subjek penelitian yang berubah dari satu subjek ke subjek lainnya adalah variabel. (Hidayat, A aziz Alimul, 2007)

Berdasarkan hasil penelitian yang diketahui distribusi responden berdasarkan karakteristik meliputi jenis kelamin, umur, pendidikan, pekerjaan, pengetahuan, sikap dan perilaku CTPS terdapat pada tabel di bawah ini.

\section{Jenis Kelamin}

Karakteristik yang terdapat pada responden berdasarkan jenis kelamin yang diperoleh sebagai berikut:

Pada tabel 1 menunjukkan bahwa jenis kelamin responden di Kelurahan Tanah Kalikedinding terdapat perempuan dengan sebesar 45 orang $(64,3 \%)$ dan sisanya 25
Tabel 1. Distribusi Frekuensi Berdasarkan Jenis Kelamin Responden di Kelurahan Tanah Kalikedinding Tahun 2016

\begin{tabular}{lcc}
\hline $\begin{array}{c}\text { Jenis } \\
\text { Kelamin }\end{array}$ & Jumlah & Persentase (\%) \\
\hline Perempuan & 45 & 64.3 \\
Laki-Laki & 25 & 35.7 \\
\hline Total & 70 & 100 \\
\hline
\end{tabular}

orang $(35,7 \%)$ adalah laki-laki sehingga mayoritas jenis kelamin yang terdapat pada Kelurahan Tanah Kalikedinding adalah jenis kelamin perempuan.

\section{Umur Responden}

Karakteristik responden berdasarkan umur yang diperoleh sebagai berikut:

Pada tabel 2 menunjukkan bahwa mayoritas umur responden di Kelurahan Tanah Kalikedinding adalah lebih dari 30 tahun dengan jumlah 38 orang $(54,3 \%)$, sedangkan umur responden yang dibawah 30 tahun sebanyak 32 orang $(45,7 \%)$.

Tabel 2. Distribusi Frekuensi Berdasarkan Umur Responden di Kelurahan Tanah Kalikedinding Tahun 2016

\begin{tabular}{ccc}
\hline Umur & Jumlah & Persentase (\%) \\
\hline 26-35 tahun & 17 & 24.3 \\
36-45 tahun & 15 & 21.4 \\
\hline Umur & Jumlah & Persentase (\%) \\
\hline 46-55 tahun & 28 & 40.0 \\
56-65 tahun & 10 & 14.3 \\
\hline Total & 70 & 100 \\
\hline
\end{tabular}

\section{Pendidikan Responden}

Karakteristik responden berdasarkan pendidikan yang diperoleh sebagai berikut:

Pada tabel 3 karakteristik responden berdasarkan pendidikan diketahui bahwa mayoritas mempunyai pendidikan SMP sebanyak 61 orang $(87,1 \%)$. 
Tabel 3. Distribusi Frekuensi Berdasarkan Pendidikan Responden

\begin{tabular}{lcc}
\hline $\begin{array}{c}\text { Pendidikan/ } \\
\text { Lulus }\end{array}$ & Jumlah & Persentase (\%) \\
\hline SD & 33 & 47.2 \\
SMP & 28 & 40.0 \\
SMA & 8 & 11.4 \\
D3 & 1 & 1.4 \\
\hline Total & 70 & 100 \\
\hline
\end{tabular}

\section{Pekerjaan Responden}

Karakteristik responden berdasarkan pekerjaan yang diperoleh hasil sebagai berikut:

Pada tabel 4 bahwa karakteristik responden berdasarkan pekerjaan mayoritas adalah wiraswasta sebanyak 40 orang $(57,1 \%)$ dan pekerjaan yang paling sedikit yaitu sebagai PNS hanya 1 orang $(1,4 \%)$.

Tabel 4. Distribusi Frekuensi Berdasarkan Pekerjaan Responden di Kelurahan Tanah Kalikedinding Tahun 2016

\begin{tabular}{lcc}
\hline Jenis Pekerjaan & Jumlah & Persentase (\%) \\
\hline Karyawan Swasta & 9 & 12.9 \\
IRT & 20 & 28.6 \\
Wiraswasta & 40 & 57.1 \\
PNS & 1 & 1.4 \\
\hline Total & 70 & 100 \\
\hline
\end{tabular}

\section{Tingkat Pengetahuan Responden}

Karakteristik responden berdasarkan pengetahuan yang diperoleh dari hasil penelitian terdapat pada tabel sebagai berikut:

Pada tabel 5 menunjukkan bahwa karakteristik responden berdasarkan pengetahuan terhadap CTPS, mayoritas memiliki pengetahuan yang baik sebanyak 52 orang $(74,3 \%)$ dan pengetahuan yang kurang sebanyak 18 orang $(25,7 \%)$.
Tabel 5 Distribusi Frekuensi Berdasarkan Pengetahuan Responden di Kelurahan Tanah Kalikedinding Tahun 2016

\begin{tabular}{lcc}
\hline $\begin{array}{c}\text { Pengetahuan } \\
\text { CTPS }\end{array}$ & Jumlah & Persentase (\%) \\
\hline Kurang & 18 & 25.7 \\
Baik & 52 & 74.3 \\
\hline Total & 70 & 100 \\
\hline
\end{tabular}

\section{Sikap Responden}

Karakteristik responden berdasarkan sikap yang diperoleh hasil sebagai berikut:

Pada tabel 6 karakteristik responden berdasarkan sikap diketahui bahwa mayoritas mendukung untuk perilaku CTPS sebanyak 65 orang $(92,9 \%)$.

Tabel 6. Distribusi Frekuensi Berdasarkan Sikap Responden di Kelurahan Tanah Kalikedinding Tahun 2016

\begin{tabular}{lcc}
\hline \multicolumn{1}{c}{ Sikap } & Jumlah & Persentase (\%) \\
\hline Mendukung & 65 & 92.9 \\
\hline Tidak Mendukung & 5 & 7.1 \\
\hline Total & 70 & 100 \\
\hline
\end{tabular}

\section{Perilaku Responden}

Karakteristik responden berdasarkan perilaku yang diperoleh terdapat di dalam tabel 7 dibawah ini:

Pada data tabel 7 karakteristik responden berdasarkan perilaku diketahui bahwa mayoritas responden tidak berperilaku baik dalam CTPS sebanyak 54 orang $(77,1 \%)$ dan responden dengan perilaku yang baik sebanyak 16 orang $(22,9 \%)$.

\section{PEMBAHASAN}

Pada penelitian yang telah dilaksanakan di Kelurahan Tanah Kalikedinding RW 
Tabel 7. Distribusi Frekuensi Berdasarkan Perilaku Responden di Kelurahan Tanah Kalikedinding Tahun 2016

\begin{tabular}{lcc}
\hline \multicolumn{1}{c}{ Perilaku } & Jumlah & Persentase(\%) \\
\hline Baik & 16 & 22.9 \\
Tidak Baik & 54 & 77.1 \\
\hline Total & 70 & 100 \\
\hline
\end{tabular}

II (RT 07 dan 11) Kecamatan Kenjeran Kota Surabaya akan menjelaskan faktor determinan perilaku CTPS dalam masyarakat yang diuraikan dari hasil penelitian.

Penelitian ini bertujuan untuk mengetahui gambaran antara jenis kelamin, umur, pendidikan, jenis pekerjaan, pengetahuan, sikap dan perilaku CTPS pada masyarakat di Kelurahan Tanah Kalikedinding RW II (RT 07 dan 11) Kecamatan Kenjeran Kota Surabaya. Penelitian ini telah dilakukan kepada 70 responden. Waktu dilakukannya penelitian selama 2 hari yaitu pada tanggal 08 sampai 11 Februari 2016. Hasil yang didapatkan dari kegiatan penelitian ini sebagai berikut:

\section{Karakteristik Responden}

Green mengatakan bahwa, terdapat tiga hal yang berpengaruh terhadap perilaku kesehatan itu sendiri, maka karakteristik responden di jelaskan berdasarkan faktor pendorong, faktor pemungkin dan faktor penguat, yaitu:

\section{Faktor pendorong (predisposing factors)}

Yang diwujud dalam pengetahuan, nilai-nilai, sikap, keyakinan kepercayaan dan variasi demografi. Dalam penelitian ini yang diteliti demografi (Jenis kelamin, umur, pendidikan, pekerjaan), pengetahuan, sikap dan perilaku.

\section{Jenis Kelamin}

Pada Kelurahan Tanah Kalikedinding RW II (RT 07 dan 11) Kecamatan Kenjeran Kota Surabaya jenis kelamin responden mayoritas adalah perempuan dengan jumlah 45 orang $(64.3 \%)$. Dalam penelitian ini perempuan memiliki peranan penting dalam berperilaku CTPS dikarenakan kegiatan yang biasanya dilakukan oleh seorang perempuan seperti menjaga kebersihan makanan agar terhindar dari bakteri sebaiknya sebelum dan setelah memasak melakukan CTPS yang benar, kemudian dalam melakukan aktivitas membersihkan rumah serta dalam mengasuh bayi maupun anak agar tetap menjaga kebersihan tangan untuk menghindari penularan dan penyebaran penyakit atau bakteri kepada bayi maupun anak.

Jenis kelamin juga dapat mempengaruhi tahap cuci tangan seseorang. Antara lakilaki dan perempuan terdapat perbedaan kebiasaan mengenai pola hidup bersih. Hal tersebut juga dapat menyebabkan perilaku cuci tangan antara laki-laki dan perempuan dapat berbeda. Dalam penelitian Johnson, et al (2003) memasang tanda peringatan yang mengingatkan orang untuk mencuci tangannya di kamar mandi umum. Dilakukan observasi terhadap 175 individu (95 wanita dan 80 pria) menyatakan bahwa $61 \%$ wanita dan $37 \%$ pria mencuci tangannya, tanpa adanya peringatan. Sedangkan $97 \%$ wanita dan $35 \%$ pria mencuci tangannya pada keadaan ada tanda peringatan.

Hal ini diteli juga oleh Van de Mortel, et al (2001), di dalam Critical Care Unit (CCU) sebuah institusi pendidikan kedokteran dan keperawatan di Australia. Dimana mereka menemukan bahwa staf CCU wanita secara signifikan mencuci tangan mereka lebih sering dibanding staf pria setelah kontak dengan pasien, dengan nilai $(\mathrm{p}=0,0001)$.

Dalam penelitian tersebut disimpulkan bahwa faktor jenis kelamin mempengaruhi tingkat cuci tangan, meskipun ini dapat berubah pada grup profesi tertentu.

\section{Umur Responden}

Perilaku terhadap cuci tangan pada air mengalir dan menggunakan sabun dengan benar pada penelitian ini ditemukan pada sebagian besar responden berumur $\geq 30$ tahun berjumlah 38 orang $(54,3 \%)$.

Menurut Sadli (2010), usia dewasa muda paling banyak tersentuh dan menyentuh perubahan sosial yang sedang berlangsung. Pada usia tersebut biasanya dijadikan sasaran dalam program pembangunan, seperti program kesehatan, gizi dan program Keluarga Berencana (KB). 
Pada usia dewasa akan lebih mudah dalam memberikan bimbingan dan arahan dalam menjaga kesehatan serta menyadari pentingnya menjaga kesehatan.

Sejalan dengan pendapat yang diungkapkan Nursalam (2007), bahwa level kedewasaan dan kekuatan setiap individu akan lebih matang dalam berpikir dan bekerja seiring dengan semakin bertambahnya umur. Karena dengan bertambahnya umur seseorang tingkat kedewasaan dalam berpikir semakin meningkat dan muncul motivasi atau dorongan dalam melakukan pekerjaan. Umur merupakan salah satu faktor risiko alami yang mempengaruhi kesehatan (Nilawati, 2008).

\section{Pendidikan Responden}

Pada penelitian ini mayoritas responden memiliki pendidikan pada tingkat menengah pertama. Menurut Notoatmodjo (2007), respon seseorang terhadap suatu hal dipengaruhi oleh tingkat pendidikan. Pada individu dengan pendidikan tinggi akan memberikan respon yang logis terhadap informasi yang datang dan akan berpikir sejauh mana signifikan didapatkan dari hal tersebut.

Pendidikan merupakan bimbingan yang diberikan seseorang termasuk perilaku seseorang terhadap pola hidup, terutama dalam memotivasi sikap yang memiliki peran serta dalam perkembangan kesehatan. Semakin tinggi tingkat kesehatan seseorang semakin mudah dalam menerima informasi sehingga makin banyak pola pengetahuan yang dimiliki. Maka dalam penelitian ini sesuai dengan teori Notoatmodjo, dikarenakan pendidikan pada responden rendah membuat perilaku CTPS tidak baik.

Mubarak (2007), mengungkapkan bahwa tidak dapat dipungkiri bahwa semakin mudah seseorang memahami informasi dipengaruhi oleh tingkat pendidikan serta semakin bertambah pula informasi yang diketahui dan sebaliknya.

Pendidikan juga dapat mempengaruhi perilaku cuci tangan seseorang. Hal tersebut didukung penelitian yang dilakukan oleh Larson, et al (1997), mengenai implementasi dari program intervensi edukasi atau feedback pada pasien di
Intensive Care Unit (ICU) dan ICU bedah. Dari penelitian tersebut diperoleh hasil setelah dilaksanakannya program pendidikan, kepatuhan dan cara mencuci tangan yang benar mengalami perubahan sedikit; ICU 14\% (sebelum diberikan pendidikan, kepatuhan dan cara mencuci tangan yang benar) dan 25\% (sesudah diberikan pendidikan, kepatuhan dan cara mencuci tangan yang benar),ICU bedah $6 \%$ (sebelum) dan 13\% (sesudah).

\section{Jenis Pekerjaan}

Berdasarkan hasil penelitian mayoritas pekerjaan di Kelurahan Tanah Kalikedinding RW II (RT 07 dan 11) Kecamatan Kenjeran Kota Surabaya adalah wiraswasta sebanyak 40 orang $(57,1 \%)$. Pekerjaan wiraswasta terbanyak adalah pedagang dimana sangat menyita waktu sehingga kurang memperhatikan diri dalam menjaga kesehatan, khususnya dalam hal mencuci tangan setelah melakukan aktivitas tidak terlalu diperhatikan.

Mubarak (2007), mengatakan, lingkungan pekerjaan membuat seseorang mendapatkan pengalaman dan informasi baik secara langsung maupun tidak langsung. Sejalan dengan penelitian Zuraidah, Yeni Elviani (2013), yang meneliti tentang hubungan pengetahuan dan sikap terhadap perilaku mencuci tangan dengan benar pada 50 responden, dengan hasil penelitian menunjukkan bahwa pengetahuan yang baik belum tentu dapat membuat seseorang untuk berperilaku cuci tangan dengan benar.

Berdasarkan penelitian yang dilakukan di Universitas Newscastle, Inggris, dengan 300 sampel yang terdiri dari 150 sampel sibuk dan 150 sampel tidak sibuk, ternyata sebesar $26 \%$ yang mencuci tangan benar pada sampel sibuk dan $67 \%$ pada sampel tidak sibuk. (Tones dan Tilford, 2001; WHO 2005).

\section{Tingkat Pengetahuan}

Berdasarkan hasil penelitian, sebanyak 52 orang $(74,3 \%)$ memiliki pengetahuan yang baik tentang perilaku CTPS dan terdapat 18 orang $(25,7 \%)$ yang memiliki pengetahuan kurang baik tentang perilaku CTPS. Dari pengalaman yang diperoleh, 
perilaku yang didasari oleh pengetahuan ternyata akan lebih bertahan lama dibandingkan dengan perilaku yang tidak didasari oleh pengetahuan (Notoatmodjo, 2010).

Pengetahuan merupakan salah satu faktor yang mempengaruhi perilaku tentang mencuci tangan, mencuci tangan merupakan suatu perilaku kesehatan (Kustanty, 2013).

Berdasarkan data dari WHO, perilaku mencuci tangan dengan sabun dapat menurunkan terjadinya kasus diare dan ISPA. Terdapat berbagai hal yang mempengaruhi rendahnya perilaku CTPS karena masih rendahnya pengetahuan dan kesadaran untuk melakukan perilaku CTPS yang benar.

Tangan merupakan media penyalur penyakit maka dengan cuci tangan yang merupakan hal mudah dan murah dapat mengendalikan risiko penyakit (promotif dan preventif). Dari hasil survei Health Service Program terdapat 98 dari 100 orang Indonesia yang tidak mencuci tangan pakai sabun setelah buang air besar. Sehingga tidak mengherankan bila banyak warga Indonesia yang masih mengalami diare dikarenakan gaya hidup yang tidak bersih maka meningkatkan pengetahuan tentang PHBS sangat dibutuhkan dalam hal ini.

Pengetahuan seseorang dapat diperoleh melalui pendidikan, pengalaman, hubungan sosial (lingkungan sosial budaya), paparan media masa (akses informasi) dan ekonomi (pendapatan). Sebagian besar responden memiliki pengetahuan yang baik mengenai perihal manfaat dan resiko perilaku CTPS yang diperoleh dari penyuluhan kesehatan dimana di selenggarakan oleh pelayanan kesehatan puskesmas setempat (Kemenkes RI, 2014).

Berdasarkan hasil penelitian, tingkat pengetahuan terhadap perilaku CTPS masyarakat termasuk tinggi yaitu sebesar $74.2 \%$ namun pengetahuan bukan merupakan faktor penentu masyarakat untuk berperilaku CTPS, sesuai dengan teori Lawrence Green dalam Notoatmodjo (2010), yang mengatakan terdapat beberapa faktor yang mempengaruhi perilaku yaitu faktor predispossing (pengetahuan) serta dipengaruhi oleh faktor reinforcing serta faktor enabling.
Teori Bloom mengungkapkan bahwa domain penting untuk terbentuknya tindakan dan penerimaan perilaku baru yang berladaskan pengetahuan bersifat long lasting pada seseorang adalah pengetahuan. Sebaliknya, apabila perilaku itu tidak disadari oleh pengetahuan dan kesadaran akan tidak berlangsung lama dan berdasarkan teori Rogers, yang menyebutkan bahwa orang yang sudah tahu (awarenes) terhadap suatu hal belum tentu dia akan berperilaku yang benar sebelum yang bersangkutan melakukan beberapa tahap sampai pada akhirnya dia mengadopsi hal tersebut dengan tepat (Wawan, 2011).

Dalam penelitian Fajar, Nur Alam dan Misnaniarti (2011), dimana hasilnya menunjukkan tidak ada pengaruh yang signifikan antara pengetahuan dengan perilaku cuci tangan pakai sabun. Menurut Green ada beberapa hal yang mempengaruhinya yaitu kepercayaan, kebiasaan, nilai-nilai, faktor sosiodemografi, lingkungan fisik dan sarana (Maulana, 2009).

Lingkungan kehidupan juga dapat memberikan pengalaman tentang berbagai hal terhadap setiap individu, contohnya buku petunjuk, media massa, media elektronik, media poster, kerabat dekat dan petugas kesehatan yang mengadakan kegiatan kesehatan. Kegiatan kesehatan yang mendidik yaitu penyuluhan kesehatan yang memberikan dan jangkauan yang luas terhadap pengalaman, sehingga dari bermacam kegiatan tersebut dapat memperoleh informasi tentang suatu hal.

\section{Sikap Responden}

Berdasarkan hasil penelitian mayoritas sikap di Kelurahan Tanah Kalikedinding RW II (RT 07 dan 11) Kecamatan Kenjeran Kota Surabaya adalah mendukung sebanyak 65 orang $(92,9 \%)$ dan yang tidak mendukung dilakukannya perilaku CTPS sebanyak 5 orang $(7,1 \%)$.

Sikap merupakan sebagian dari perilaku manusia. Didalam suatu pembentukkan atau perubahan, terdapat beberapa hal yang mempengaruhi perilaku baik dari internal individu yaitu susunan saraf pusat, motivasi dan emosi sedangkan dari eksternal individu seperti lingkungan (Wawan, 2011). 
Sikap adalah suatu reaksi tertutup, bersifat intagible, merupakan kesiapan atau kesediaan untuk bertindak. Sikap belum merupakan suatu tindakan akan tetapi merupakan predisposisi tindakan atau perilaku. Sikap dapat diukur dengan dua cara yaitu langsung dan tidak langsung. Menanyakan bagaimana opini atau pertanyaan responden terhadap suatu objek merupakan cara langsung, dalam penelitian ini dilakukan pertanyaan mengenai perilaku CTPS terhadap responden, sebagian besar responden mendukung akan perilaku CTPS (Wawan, 2011).

Terdapat 10 Indikator PHBS dimana salah satunya adalah mencuci tangan dengan air bersih dan sabun sebelum dan sesudah makan, sesudah buang air besar (BAB) dan buang air kecil (BAK). Keberdayaan masyarakat yang sadar, mau dan mampu mempraktekkan perilaku hidup bersih dan sehat dimana faktor perilaku secara teori mempunyai bagian sebesar 30-35\% terhadap derajat kesehatan, serta perilaku memberikan dampak yang cukup besar terhadap derajat kesehatan maka dibutuhkan bermacam upaya untuk merubah perilaku menjadi sehat, salah satunya melalui program Perilaku Hidup Bersih dan Sehat (PHBS) (Kemenkes RI, 2014).

Berdasarkan data dari penelitian, hasil dari penelitian menunjukkan bahwa masyarakat bersikap mendukung berperilaku CTPS. Notoatmodjo (2010), mengungkapkan bahwa suatu sikap belum pasti terealisasi dalam suatu tindakan (over behavior). Untuk mengimplementasikan sikap menjadi suatu tindakan nyata dibutuhkan suatu kondisi yang memungkinkan, misalnya adalah fasilitas.

Disamping faktor pemungkin, juga dibutuhkan faktor pendukung (support) yang di dapatkan dari pihak lain. Dari hasil penelitian terdapat $92.8 \%$ mendukung perilaku CTPS tetapi terdapat $77.1 \%$ masyarakat berperilaku tidak mencuci tangan menggunakan sabun. Memahami sikap dan perilaku manusia merupakan aspek yang sangat penting dalam pengungkapan (assesment) atau pengukuran (measurement) sikap. Hal itu merupakan respons evaluatif yang dapat berbentuk suatu dampak baik atau buruk (Wawan, 2011).
Penilaian yang bisa berupa pendapat seseorang terhadap stimulus dan objek dalam hal ini adalah masalah kesehatan, termasuk penyakit yang diketahui merupakan sikap. Setelah responden mengetahui mengenai bahaya tidak mencuci tangan (melalui pengalaman, pengaruh orang lain, media massa, lembaga pendidikan, emosi), proses selanjutnya akan menilai atau bersikap terhadap kegiatan mencuci tangan tersebut, dengan adanya pengetahuan yang baik serta sikap yang mendukung terhadap perilaku CTPS diharapkan mampu membuat responden berperilaku CTPS tetapi dalam penelitian ini masih dibutuhkan kesadaran individu dalam terwujudnya perilaku CTPS dikarenakan masih rendahnya perilaku CTPS pada masyarakat Kelurahan Tanah Kalikedinding.

\section{Perilaku Responden}

Pada penelitian ini terdapat perilaku CTPS yang tidak baik sebanyak 54 orang $(77,1 \%)$ dan yang berperilaku baik dengan mencuci tangan pakai sabun sebanyak 16 orang $(22,9 \%)$. Sesuatu yang paling penting dalam mewujudkan perilaku kesehatan adalah masalah pembentukan dan proses perubahan perilaku. Pengukuran atau cara mengamati perilaku terdapat dua cara yaitu, secara langsung maupun secara tidak langsung, pengukuran perilaku yang paling baik adalah secara langsung, yakni dengan pengamatan (observasi) yaitu mengamati tindakan dari subjek dalam rangka memelihara kesehatannya. Metode tidak langsung adalah dengan menggunakan mengingat kembali (recall), (Notoatmodjo, 2010).

World Health Organization (WHO) melakukan sebuah penelitian yaitu upaya yang dapat dilakukan untuk menurunkan angka kejadian diare dan ISPA yaitu perilaku cuci tangan pakai sabun. Salah satu tindakan dengan membersihkan tangan dan jari jemari menggunakan air dan sabun oleh manusia untuk menjadi bersih dan memutuskan mata rantai kuman yang disebut mencuci tangan dengan sabun.

Hasil penelitian ini didukung oleh penelitian Burton, Cobb, Donachie, Judah, Curtis dan Schmidit (2011) dan Pickering, Boehm, Mwanjali dan Davis (2010), 
menunjukkan bahwa cuci tangan dengan menggunakan sabun lebih efektif dalam memindahkan kuman dibandingkan dengan cuci tangan hanya dengan menggunakan air. Penelitian ini juga menunjukkan bahwa penyediaan sarana air bersih baik itu di sekolah dasar maupun rumah sebagai sarana untuk cuci tangan juga sudah baik.

Semakin baik ketersediaan sarana cuci tangan pakai sabun (CTPS) pada setiap rumah akan semakin baik CTPS pada ibu rumah tangga untuk menghindari penyakit diare dan ISPA. Hal ini sejalan dengan penelitian Ambarwati dalam Utami (2010) yang tertulis dalam penelitiannya bahwa tidak ada pengaruh yang bermakna pada perilaku cuci tangan oleh kelompok yang menyatakan sarana tidak memadai dengan kelompok yang menyatakan sarana memadai.

Dalam kehidupan sehari-hari perilaku dapat dipengaruhi karena adanya persepsi. Stimulus yang diperoleh oleh seseorang memiliki perbedaan maka menimbulkan suatu persepsi yang berbeda antar individu (Satriadi, 2011). Sedangkan John Ivancevich (2006), mengatakan ada hubungan antara persepsi dengan perilaku, dimana individu melalui tindakan, bahasa tubuh, dan cara bicara, berusaha menciptakan suatu kesan tertentu dalam persepsi orang lain.

Namun tidak sesuai dengan penelitian Zuraidah (2013), dalam hubungan pengetahuan dan sikap terhadap perilaku mencuci tangan dengan benar pada kelas V SD, hasil analisis yang menyatakan bahwa sebanyak 50 responden yang mencuci tangan dengan benar adalah 41 responden dengan pengetahuan baik dan dari hasil analisisnya mengatakan bahwa ada hubungan pengetahuan dengan perilaku mencuci tangan pakai sabun pada kelas $\mathrm{V}$ sekolah dasar.

Woodhworth mengatakan bahwa motivasi atau dorongan akan menciptakan sebuah perilaku. Dengan dorongan tersebut, akan memberikan suatu keyakinan terhadap seseorang untuk melakukan perilaku tersebut. (Wawan, 2011).

\section{Faktor pemungkin (enabling factors)}

Yang terjadi dalam lingkungan fisik, terdapatnya sarana dan prasarana atau fasilitas kesehatan bagi masyarakat. Dalam penelitian ini responden memiliki air bersih yang mencukupi dan tempat untuk mencuci tangan. Namun hal tersebut masih belum dapat merubah atau mendukung masyarakat dalam berperilaku CTPS.

\section{Faktor penguat (reinforcing factors)}

Yang realisasinya dalam sikap dan perilaku tenaga kesehatan yang merupakan panutan dari perilaku masyarakat, sehingga promotif dan preventif kesehatan yang efektif adalah meningkatkan promosi kesehatan yang berkelanjutan dan membuat pelatihan bagi tokoh masyarakat, kader dan tenaga kesehatan, agar sikap dan perilaku petugas, kader dan tokoh masyarakat dapat menjadi teladan atau acuan bagi masyarakat tentang perilaku hidup bersih dan sehat (Notoatmodjo, 2010).

Dalam penelitian ini tenaga kesehatan telah memberikan penyuluhan perilaku hidup bersih dan sehat yang dilakukan pada saat posyandu balita, lansia dan saat pelayanan di puskesmas.

\section{SIMPULAN}

Hasil penelitian dapat disimpulkan dalam hal-hal sebagai berikut:

Karakteristik responden pada penelitian ini menggambarkan jenis kelamin, umur, pendidikan, jenis pekerjaan, pengetahuan, sikap dan perilaku. Responden terbanyak perempuan sebanyak 45 orang $(64.3 \%)$, dengan rentan umur 45-55 tahun sebanyak 28 orang $(40 \%)$, lulus pendidikan SMP sebanyak 28 orang $(40 \%)$, pekerjaan wiraswasta sebanyak 40 orang $(57.1 \%)$, pengetahuan yang baik tentang CTPS sebanyak 52 orang $(74.3 \%)$, sikap dan perilaku dalam penelitian menunjukkan 65 orang $(92,9)$ mendukung dalam CTPS namun dalam pelaksanaan CTPS mayoritas responden tidak berperilaku baik dalam CTPS sebanyak 54 orang $(77,1 \%)$.

Penelitian ini mengambarkan determinan mencuci tangan dengan benar dan memakai sabun ditentukan oleh perilaku diri sendiri dalam menjaga kesehatannya, serta menunjukkan bahwa peran sikap dalam perilaku CTPS merupakan dukungan dalam tercapainya perilaku CTPS yang benar. 
Kesehatan dengan perilaku memiliki hubungan yang berkesinambungan, seseorang yang sehat akan terlihat dari perilaku yang sehat pula. Sesuai dengan hal tersebut maka perilaku yang sehat akan menggambarkan seseorang yang memiliki kualitas hidup baik. Sehingga perlu di tingkatkan kesadaran masyarakat dalam perilaku CTPS.

\section{SARAN}

Disarankan hal-hal sebagai berikut kepada pemberi pelayanan kesehatan seperti puskesmas setempat: Mengupayakan kegiatan penyuluhan secara terprogram dan berkelanjutan dalam mewujudkan perilaku CTPS secara merata di setiap daerah. Mengupayakan evaluasi dan monitoring secara berkala pada setiap program kegiatan CTPS di masyarakat. Melibatkan lintas sektor dalam setiap program kegiatan CTPS di masyarakat.

Untuk masyarakat di Kelurahan Tanah Kalikedinding hendaknya menjaga perilaku hidup bersih melalui kegiatan CTPS, sebaiknya dilakukan sebelum dan sesudah melakukan kegiatan.

Bagi peneliti selanjutnya disarankan untuk meneliti tentang variabel lainnya yang dapat mempengaruhi perilaku mencuci tangan dengan sabun misalnya motivasi.

\section{DAFTAR PUSTAKA}

Burton, M., Cobb, E., G,Curtis, V Donachie, P., Judah., Schmidit, W. 2011. The effect of handswashing with water or soap on bacterial contamination of hands. Int. J. Environ. Res. Public Health, 8, 97-104. doi:10.3390/ijerph8010097

Desiyanto., \& Djannah.2013.Efektifitas Mencuci Tangan Menggunakan Cairan Pembersih Tangan Antiseptik (Hand Sanitizer) Terhadap Jumlah Angka Kuman, Jurnal Kesehatan Masyarakat,Vol.2 No.2.

Green, L.1980. Health Education Planning-a Diagnostic Approach. Mayfield Publishing Co, johns Hopkins University, Boston.

Grayson et al .2009. Efficancy Of Soap And Water And Alchol Based Hand Rub.
United States. Vol 18. No:4:08-CR0002

Fajar, N. 2011. Hubungan Pengetahuan dan Sikap terhadap perilaku Cuci Tangan Pakai Sabun Pada Masyarakat Di Desa Senuro Timur. Jurnal Pembangunan Manusia, Vol.5, No. 1, Tahun 2011

Machfoedz, I., Suryani. 2008. Pendidikan Kesehatan Bagian Dari Promosi Kesehatan. Fitramaya: Yogyakarta

Kemenkes - Direktorat Penyehatan Lingkungan. 2013. Buku Panduan Penyelenggaraan Kegiatan HCTPS Sedunia 2013. Dirjen Pengendalian Penyakit dan Penyehatan Lingkungan. Jakarta.

Kemenkes, R.I. 2013.Profil Kesehatan Indonesia.Jakarta

Kemenkes, R.I. 2014.Profil Kesehatan Indonesia.Jakarta

Kustantya, N. 2013. Karakteristik Keluarga tentang Perilaku Hidup Bersih dan Sehat (PHBS) pada Tatanan Rumah tangga di Desa Karangasem. Jurnal gaster, Vol. 8 , No. 2

Larson, et al.1997; Efficancy Of Soap And Water. Res.Public Health, 8, 97-104. doi:11.3390/ijerph8011077

Lestari, D. 2008. Metode Expository Teaching terhadap Perilaku CTPS, Skripsi Universitas Katolik Soegijapranata

Maulana, H. 2009. Promosi Kesehatan. Jakarta: EGC

Notoadmodjo, S. 2010. Promosi kesehatan teori dan aplikasi. Jakarta: Rineka Cipta .

Notoadmodjo, S. 2010. Ilmu perilaku kesehatan. Jakarta: Rineka Cipta.

Palancoi, NA. 2014. Hubungan pengetahuan dan lingkungan dengan diare akut pada anak di kelurahan pabbundukang kecamatan pangkajane kabupaten pangkep. Jurnal Kesehatan. Volume VII. No 2/2014

Pickering, A.J, Mwanjali, M, Boehm,A.B \& Davis, J. 2010. Efficacy of waterless hand hygiene compared with handwashing with soap : a field study in Dar es Salaam. Tanzania Am. J. Trop. Med. Hyg. 82 (2). 270-278. Doi : 10. 4269/ajtmh. 2010. 09-0220

Sadli, S.2010. Pemikiran Tentang Kajian Perempuan. Jakarta: PT Kompas Media Nusantara 
Kumar, S., Sebastian. 2011. "Does improved sanitation reduce diarrhea in children in rural India?. Journal of Harvard School of Public Health.

Undang-Undang Republik Indonesia No. 36 tahun 2009 tentang Kesehatan

Utami, W. 2010. Faktor-Faktor Yang Berhubungan Dengan Kebiasaan Cuci Tangan Pakai Sabun Pada Masyarakat Di Desa Cikoneng Kecamatan Ganeas Kabupaten Sumedang Tahun 2010.
Wawan. 2011. Teori dan Pengukuran Pengetahuan, Sikap dan Perilaku Manusia. Nuha Medika : Yogyakarta

WHO. 2005. A Lively and Healthy Me, diakses tanggal 10 April 2016 pukul 12.30

Zuraidah, Y. 2013. Hubungan Pengetahuan dan Sikap Dengan Perilaku Mencuci Tangan Dengan Benar Pada Siswa SD Kota Lubuklinggau Tahun 2013. Jurnal fakultas keperawatan. Politeknik Kesehatan Palembang 